\title{
Alguns comentários sobre o tema
}

\author{
Some comments on the topic
}

Algunos comentarios sobre el tema

O tema ganhou excepcional atualidade, além de ser altamente complexo. Acredito que vivemos um momento histórico e de inflexão no assunto provimento de profissionais de saúde (entre eles, os médicos) para as necessidades da população brasileira. O artigo enviado para a discussão tem grandes méritos, e alguns pontos que, imagino, poderiam ter sofrido maior reflexão. Localiza, já no resumo, um dos cernes da questão: a educação.

Portanto, uma das matrizes de discussão proposta é o modelo de formação e a necessidade de educação permanente, em especial, para a atenção básica, que é a estrutura da organização de todos os países que conseguiram viabilizar seus sistemas de saúde. Para encarar a situação brasileira, temos um problema quali e quantitativo. Nosso modelo formador atual não forma para uma boa prática em $A B$, e estamos formando muito poucos médicos no Brasil (temos muitas faculdades, mas com poucos alunos cada uma), além de estarem mal distribuídos. As residências, que formam para as especialidades embora sustentadas pelo governo, não atendem às necessidades da população brasileira em sua grande maioria. Isso está bem localizado no artigo, que conta, ainda, com categorias de análise muito consistentes.

Acredito, porém, que deveríamos ser mais generosos com os antecedentes históricos que tentaram resolver a questão da formação de médicos adequados para a realidade brasileira. Nas décadas de 1970 a 1990, imaginávamos (nós, do movimento sanitário, como proposta organizativa) que poucos médicos eram atraídos para a saúde coletiva, para a Medicina Comunitária (hoje, chamada de Família) em função da baixa oferta salarial e de não existir essa demanda, como mercado de trabalho. As primeiras iniciativas de enfrentar essa situação datam do PIASS, da Residência em Medicina Comunitária do Murialdo ou da Reforma Curricular da UFMG, todas em 1976. No pós-ditadura, para acelerar o provimento, após a criação do SUS, foi instituído o PSF, com salários mais atrativos, que fornecia subsídios governamentais para fixação. A resposta foi pífia e correspondia a recémformados - que ainda não tinham sido aprovados nas residências sonhadas e, após seis meses ou um ano, abandonavam seu posto de trabalho novamente em busca da residência - ou a médicos aposentados em cidades grandes, buscando qualidade de vida no interior do país.

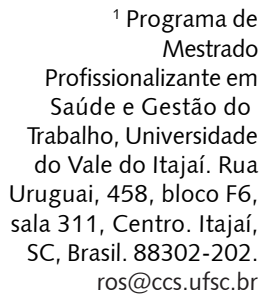
ros@ccs.ufsc.br 
Especialmente com a experiência do CINAEM, "descobriu-se" que as faculdades, em sua maioria, estavam ensinando dentro da lógica flexneriana e de sustentação ao complexo médico-industrial (portanto: hospital, exames, remédios, seguro-saúde). Tratava-se, pois, de modificar o modelo formativo. Para isso, as diretrizes curriculares nacionais (DCN), aprovadas em 2001, pareciam ser a saída. Como elas, na prática, não se efetivaram, o governo, em 2002, lança o edital do Pró-Med para estimular as mudanças curriculares na direção das DCNs. Acreditando na sua eficácia, o governo amplia, no ano seguinte, e abre, para outros cursos da área da saúde, o Pró-saúde.

É possível que tais políticas tenham tido algum grau de impacto (não mensurado adequadamente), mas, na prática, o problema continuava como se nenhuma medida tivesse sido tomada.

Acho importante essa história para o debate a fim de que se enfatizem as diversas tentativas criação do PSF, salários consequentes, DCN, estímulo para mudanças curriculares, ampliação de vagas para residências em MFC (que não são preenchidas) e bolsas para preceptores-tutores nas UBSs (com o programa PET) - e como tudo isso parece não mexer com o imaginário dos médicos em relação às necessidades da população.

É nesse contexto, pós-experiências, que não resultaram em melhoria significativa da atenção/ distribuição dos médicos, que surge um novo discurso/programa no MS, o PROVAB, inequivocamente o tema central da análise deste artigo.

A contextualização anterior serve não apenas para reforçar a bibliografia utilizada pelos autores, que localizam as causas, mas, também, para ampliar a noção de que é um problema de altíssima complexidade, e a categoria médica não responde às expectativas propostas pelos programas.

O Provab ainda não tem uma avaliação analítica de seus resultados, até pela localização temporal, mas já se adiantam algumas coisas pelas leituras da imprensa e pelos informes ministeriais. Sua procura é pequena, atende à necessidade dos médicos de conquistarem os $10 \%$ de pontos a mais para a busca de vaga em uma residência; são preenchidas vagas em cidades grandes ou do litoral; a supervisão é insuficiente, e não fixa os médicos.

Ao final do ano de 2012, em reunião nacional de prefeitos, ficou claro que era necessária uma política mais agressiva para resolver o problema da falta de médicos. No primeiro semestre deste ano (2013), foi apresentado, por meio da MP 621, o programa Mais Médicos para o Brasil, que desencadeou uma reação imensa, tanto da categoria médica como da imprensa.

O desejo dos médicos é: trabalhar em cidade grande ou de litoral, especializar-se em tecnologia dura e receber altos salários, consultório privado, hospital, especialidade de ponta; e sentem-se inseguros e despreparados para enfrentar os desafios impostos pela tecnologia leve, e o trabalho no interior.

Não se dispõem a ir para pequenas cidades do interior da Amazônia, ou do Nordeste, mesmo com altos salários, e justificam que é por não terem disponibilidade de equipamentos de alta tecnologia ou planos de carreira. É nesses locais, porém, que habitam, pelo menos, trinta milhões de brasileiros e não podem esperar esses equipamentos para serem atendidos. Vão morrer antes, de diarreia, infecção respiratória, hipertensão e doenças por falta de vacinação. Esses médicos também não se dispõem a fazer uma avaliação de sua capacidade médica ao finalizar seu curso (um revalida para os brasileiros formados aqui). Reagem, de forma fascista, à chegada de médicos estrangeiros; sentem-se ameaçados; querem o Revalida só para esses médicos, não querem modificação no tempo de formatura. Ou seja: expõem-se, enfim, as origens de classe e o tamanho do desafio para se cumprir um SUS como foi imaginado.

A polêmica, é provável, ainda vai durar algum tempo, mas, seguramente, só a vinda de médicos do exterior também não irá resolver o provimento dos médicos. É mais uma medida paliativa. É preciso mexer com ideologia, com trabalho em equipe, com os outros profissionais. E, sobretudo, alterar a política formativa, aliando a perspectiva de emprego somente para os formados, conforme a necessidade do povo - em quantidade e qualidade boa. Cuba, um país pobre, conseguiu reverter os indicadores de saúde e, hoje, tem o maior índice de médicos por mil habitantes do mundo. $O$ momento é de enfrentamento deste nó. O artigo foi escrito quando se abria a tempestade, que, agora, continua. Vai ser histórico também. 